\title{
Proheksadioni-kalsium lisää mansikan satopotentiaalia avomaalla
}

\author{
Katriina Mouhu' ${ }^{1)}$, Ilpo Koivu'), Olavi Junttila'a ja Timo Hytönen ${ }^{1)}$ \\ ${ }^{1)}$ Helsingin yliopisto, Soveltavan biologian laitos, PL 27 (Latokartanonkaari 5-7), 00014 Helsingin \\ yliopisto,katriina.mouhu@helsinki.fi \\ ${ }^{2)}$ Faculty of Science, Department of Biology, Dramsveien 201, University of Tromsø, N-9037 Tromsø, \\ Norway
}

\section{Tiivistelmä}

Puutarhamansikka (Fragaria x ananassa Duch.) on Suomen tärkein viljelty marja. Mansikan juurakko koostuu lyhyistä nivelväleistä, joissa on yksi lehti ja hankasilmu. Hankasilmu voi pysyä lepotilaisena tai se voi erilaistua joko sivujuurakoksi tai rönsyksi. Kukinto muodostuu juurakon kärkisilmuun, jolloin ylin hankasilmu jatkaa vegetatiivista kasvua. Taimeen muodostuvien kukintojen lukumäärä on siten riippuvainen sivujuurakoiden määrästä. Mansikan hankasilmujen erilaistuminen on päivänpituuden säätelemää. Syksyllä päivänpituuden lyhetessä hankasilmuista alkaa muodostua sivujuurakoita. Päivänpituuden edelleen lyhentyessä sekä lämpötilan laskiessa kukintojen aiheet alkavat muodostua juurakoiden kärkisilmuihin. Kasvu pysähtyy ja kukintoaiheiden muodostuminen loppuu talveksi. Keväällä kasvu elpyy ja kukinta alkaa. Päivän pidentyessä alkaa rönsyjen erilaistuminen hankasilmuista. Suomessa satokauden aikana alkava rönsyntuotanto on voimakasta ja vähentää seuraavan vuoden satoa merkittävästi.

Proheksadioni-kalsium (ProCa) on gibberelliinisynteesi-inhibiittori, jonka on havaittu vähentävän rönsynmuodostusta ja lisäävän sivujuurakoiden muodostumista mansikalla. Helsingin yliopiston Soveltavan biologian laitoksella selvitettiin ProCan vaikutusta Polka-lajikkeen kesällä 2004 avomaalle istutettujen taimien kasvuun ja sadontuotantoon. Taimet käsiteltiin ProCalla noin kuukausi istutuksen jälkeen heinäkuussa 2004 ja niiden kasvua ja sadonmuodostusta seurattiin syksyllä ja seuraavana kesänä. Lisäksi kasvukauden 2004 lopulla määritettiin liukoiset sokerit, tärkkelys- ja ravinnepitoisuudet.

Vuonna 2004 ProCa lyhensi lehtiruotien pituutta lyhytaikaisesti. Lehtiruotien kasvussa oli havaittavissa lievä voimistuminen kuukausi käsittelyn jälkeen. ProCa kaksinkertaisti sivujuurakoiden määrän ja vähensi rönsyjen määrää kolmanneksella. ProCalla ei ollut vaikutusta glukoosin, sakkaroosin, tärkkelyksen eikä ravinteiden pitoisuuksiin eri kasvinosissa. Seuraavana kesänä ProCa lisäsi kukintojen määrää kolmanneksella sekä hidasti kukinnan ja sadon alkamista muutamalla päivällä. ProCa puolitoistakertaisti taimesta saatavan sadon ja marjojen määrän, mutta ei vaikuttanut marjakokoon.

Tutkimuksen perusteella istutusvuonna annetulla yhdellä ProCa-käsittelyllä voidaan vähentää mansikan loppukesän rönsynmuodostusta ja lisätä sivujuurakoiden muodostumista, sekä siten kasvattaa seuraavan vuoden marjasatoa.

\section{Asiasanat}

mansikka, avomaaviljely, proheksadioni-kalsium, rönsynmuodostus, juurakonmuodostus, sadonmuodostus 


\section{Johdanto}

Puutarhamansikka (Fragaria x ananassa Duch.) on Suomen tärkein viljelty marja. Mansikka kuuluu Rosaceae-heimon ruusukekasveihin (Dana 1981, Guttridge 1985). Mansikan juurakko koostuu lyhyistä nivelväleistä, joissa on yksi lehti ja hankasilmu. Hankasilmu voi pysyä lepotilaisena tai se voi erilaistua joko rönsyksi tai sivujuurakoksi (Guttridge 1985, Robertson \& Wood 1954). Kukinnot muodostuvat juurakon ja sen haarojen kärkisilmuista, jolloin ylin hankasilmu jatkaa vegetatiivista kasvua. Kukintojen lukumäärä on siten riippuvainen juurakon haarojen määrästä. Päivänpituus säätelee sekä hankasilmujen erilaistumista että kukka-aiheiden muodostusta. Pitkänpäivänoloissa hankasilmuista erilaistuu rönsyjä ja lyhyenpäivänolot käynnistävät sivujuurakoiden ja kukka-aiheiden muodostuksen (Dana 1981, Hytönen ym. 2004). Suomen oloissa mansikan satopotentiaalin muodostus alkaa elokuun loppupuolella, kun juurakon haaroittuminen ja kukka-aiheiden muodostus käynnistyy. Kukinnot kasvavat esiin ja tuottavat sadon seuraavana keväänä. Päivän pidentyessä keväällä alkaa myös rönsyntuotanto hankasilmuista. Rönsyntuotanto on voimakkaimmillaan keskikesällä satokauden loputtua.

Kasvihormonien roolia mansikan hankasilmujen erilaistumissa on selvitetty muutamissa tutkimuksissa. Gibberelliinin on havaittu edistävän mansikan rönsynmuodostusta (Thompson \& Guttridge 1959) ja gibberelliinisynteesi-inhibiittorit lisäävät juurakon haaroittumista ja vähentävät rönsynkasvua (Nishizawa 1993, Black 2004). Proheksadioni-kalsium (ProCa) on gibberelliinisynteesiinhibiittori, joka estää aktiivisen gibberelliinin muodostumista väliaikaisesti (Griggs ym. 1991, Rademacher 2000). ProCaa on tutkittu useilla kasveilla, kuten mm. omenalla, päärynällä, vehnällä, öljyrapsilla, petunialla ja ahkeraliisalla (Grossmann ym. 1994, Ilias \& Rajapakse 2005, Rademacher ym. 2004). Kaikilla tutkituilla kasveilla ProCa lyhentää verson pituuskasvua lyhentämällä nivelvälien pituutta. Omenan ja päärynän satoon ProCa ei vaikuta merkittävästi tai lievästi lisää sadon määrää (Glenn \& Miller 2005, Medjdoub ym. 2005, Rademacher ym. 2004, Sugar ym. 2004). ProCaa on tutkittu jonkin verran myös mansikan kasvunsäädössä Yhdysvalloissa ja Kanadassa (Black 2004, Reekie \& Hicklenton 2002).

ProCa on käytössä Euroopassa Regalis ${ }^{\circledR}$ - ja Pohjois-Amerikassa Apogee ${ }^{\circledR}$-nimisenä kauppavalmisteena omenan kasvunsäätöön. ProCan hyviä puolia ovat sen vesiliukoisuus, matala myrkyllisyys mm. mehiläisille sekä lyhyt puoliintumisaika kasveissa (Evans ym. 1999). Euroopassa ProCalle on selvitetty käyttösuosituksia omenan ja päärynän kasvunsäätöön (Rademacher \& Kober 2003).

Voimakas rönsyntuotanto keskikesällä vähentää mansikan satopotentiaalia Suomen oloissa, koska se kuluttaa resursseja juurakoiden kasvulta ja kukintojen muodostumiselta. ProCan tiedetään vähentävän rönsynmuodostusta mansikalla (Black 2004, Reekie \& Hicklenton 2002). Yhdysvalloissa tehdyssä tutkimuksessa vähentyneen rönsynmuodostuksen ei kuitenkaan havaittu vaikuttavan seuraavan vuoden satoon (Black 2004). Tämän tutkimuksen tarkoituksena oli selvittää ProCan vaikutuksia avomaaviljelyssä Suomen oloissa. Kesäkuussa istutetulle Polka-lajikkeen taimille annettiin noin kuukausi istutuksen jälkeen kaksi erivahvuista ProCa-käsittelyä. Tavoitteena oli selvittää istutusvuonna annettujen ProCa-käsittelyjen vaikutusta rönsyn- ja sivujuurakoiden muodostukseen käsittelyn jälkeisenä syksynä sekä sadonmuodostukseen käsittelyä seuraavana vuonna.

\section{Aineisto ja menetelmät}

Polka-lajikkeen yksijuurakkoiset rönsypistokkaat istutettiin paririveihin mansikkamuovilla päällystettyihin ja tihkuletkuilla varustettuihin penkkeihin 15.06.2004. Yhdelle koeruudulle istutettiin 10 tainta ja kaksi suojatainta molempiin koeruutujen rivien päihin. ProCa-käsittely (BASF BAS 125 10W) annettiin 19.07. sumuttamalla taimet märiksi yksitellen käsisumupullolla sangon sisällä. ProCa annettiin 0,100 ja 200 ppm (aktiivinen ainesosa) vahvuisena vesiliuoksena, johon oli lisätty 2-3 tippaa Tween 20:tä. Yli $20 \mathrm{~cm}$ pituiset rönsyt poistettiin kasveista ennen käsittelyä. Taimia lannoitettiin tarvittaessa Mansikan puutarhalannoksella (N-P-K 7-4-27, Kemira GrowHow Oyj) ja Kastelukalkkisalpietarilla ( N-P-K 15,5-0-0 16 \% Ca, Kemira GrowHow Oyj) Kemiran lannoitusohjeiden mukaisesti.

Nuorimman esiinkasvaneen lehden ruoti merkittiin ProCa-käsittelyn yhteydessä sekä kahden ja neljän viikon kuluttua käsittelystä. Ruotien lopullinen pituus mitattiin 30.9 lehtiruodin tyveltä lehdyköiden haarautumiskohtaan. Rönsyjen lopullinen määrä laskettiin, rönsyt poistettiin ja juurakon haarat laskettiin 29.10. ProCan vaikutus sokeri- ja ravinnepitoisuuksiin sekä kuiva-aineen määrään 
(\%) analysoitiin lehdistä, rönsyistä, juurakoista ja juurista kahdesta käsittelykonsentraatiosta: 0 ja 100 ppm. Sokerit ja tärkkelys analysoitiin Megazymen kiteillä (Sucrose/Glucose Assay Procedure ja Total Starch Assay Procedure: Amyloglucosidase/a-amylase Method) Soveltavan biologian laitoksella ja mineraalit analysoitiin röntgendifraktometrillä Kemira GrowHow Oyj:n tiloissa Espoossa. Vuonna 2005 mitattiin keväällä ensimmäisen esiinkasvaneen lehden ruodin pituus sekä neljä viikkoa myöhemmin kehittyneen lehtiruodin pituus. Kukintojen määrä laskettiin viikolla 26 ja kauppakelpoisen sadon määrä mitattiin 1-3 kertaa viikossa satokauden loppuun asti.

Koe järjestettiin täydellisesti satunnaistettujen lohkojen kokeena, jossa oli yksi kolmetasoinen käsittely. Tulokset analysoitiin SAS-ohjelmiston GLM-proseduurilla ja parittaiset vertailut kontrollikäsittelyn kanssa tehtiin PDIFF-käskyllä käyttämällä sovitettuja keskiarvoja (LSMEANS). Rönsyjen, sivujuurakoiden, kukintojen ja sadon määrien testaamiseen käytettiin yksisuuntaisia hypoteeseja. Glukoosin, sakkaroosin ja tärkkelyksen määrien sekä ravinnepitoisuuksien ja lehtiruotien pituuksien testaamiseen käytettiin kaksisuuntaisia hypoteeseja. Istutusvuonna kukkineet taimet poistettiin kokeesta.

\section{Tulokset ja tulosten tarkastelu}

\section{Vuoden 2004 mittaukset}

Proca vähensi rönsyjen määrää odotetusti (Taulukko 1). Laimeampi käsittely vähensi rönsyjen määrää kontrolliin verrattuna kymmeneksen ja vahvempi jo kolmanneksella. Matalat, alle $100 \mathrm{ppm}$ pitoisuudet eivät vaikuta rönsyjen määrään merkitsevästi myöskään Chandler-, Camarosa ja Sweet Charlie -lajikkeilla, mutta jo 120 ja 125 ppm -vahvuiset käsittelyt vähentävät rönsyjen määrää merkitsevästi (Black 2004, Reekie \& Hicklenton 2002). Yli 200 ppm vahvuinen käsittely vähensi rönsyjen määrää voimakkaasti Chandler-lajikkeella (Black 2004).

Taulukko 1. Proheksadioni-kalsiumin vaikutus mansikan taimien keskimääräiseen rönsyjen lukumäärään ja rönsyjen painoon 14 viikkoa käsittelyn jälkeen. Keskiarvo \pm keskihajonta, vaihtoehtohypoteesi on yksisuuntainen $\mathrm{H}_{1}<$ kontrolli.

\begin{tabular}{lrllllllll}
\hline ProCakäsittely & \multicolumn{3}{c}{ lukumäärä $(\mathrm{kpl})$} & \multicolumn{5}{c}{ paino $(\mathrm{g}) / \mathrm{kpl}$} \\
\hline $0 \mathrm{ppm}$ & 12,3 & \pm & 0,2 & & & 148 & \pm & 29 & \\
$100 \mathrm{ppm}$ & 11,2 & \pm & 0,7 & $*$ & & 104 & \pm & 22 & 0 \\
$200 \mathrm{ppm}$ & 8,4 & \pm & 1,2 & $* * *$ & & 86 & \pm & 11 & $*$ \\
\hline
\end{tabular}

Kontrollikäsittelyn taimiin muodostui käsittelyä seuraavan syksyn aikana silmin havaittavia sivujuurakoita keskimäärin 2,7 kpl. ProCa lisäsi sivujuurakoiden muodostusta merkitsevästi molemmilla pitoisuuksilla (vaihtoehtohypoteesi oli yksisuuntainen $\mathrm{H}_{1}>$ kontrolli): $100 \mathrm{ppm}$-käsittelyn taimiin sivujuurakoita muodostui keskimäärin $5,4 \mathrm{kpl}(\mathrm{p}$-arvo $=0,003)$ ja $200 \mathrm{ppm}$-käsittelyn taimiin $7,4 \mathrm{kpl}$ (p-arvo=0,0001). Myös Black (2004) havaitsi, että yli 200 ppm vahvuinen käsittely edisti sivujuurakoiden muodostumista parhaiten.

ProCa esti käsittelyn aikaan esiinkasvaneiden lehtiruotien pituutta, mutta ei vaikuttanut kaksi ja neljä viikkoa käsittelyn jälkeen esiinkasvaneiden ruotien pituuteen (Taulukko 2). Myös aikaisemmissa tutkimuksissa ProCan on havaittu vähentävän lehtiruotien pituuskasvua väliaikaisesti (Reekie \& Hicklenton 2002, Black 2004). ProCan puoliintumisaika kasveissa on noin kaksi viikkoa (Evans ym. 1999). ProCan vähitellen hajotessa aktiivista gibberelliiniä alkaa muodostua kasveissa uudelleen. Kasvien saaman tehoaineen kokonaismäärä ratkaisee ProCan vaikutuksen voimakkuuden ja keston.

ProCa ei vaikuttanut glukoosin, sakkaroosin, tärkkelyksen eikä ravinteiden pitoisuuksiin mansikan eri kasvinosissa. Sen sijaan nuorilla omenapuilla loppukesän ProCa-käsittely lisää eirakenteellisten hiilihydraattien ja typen määrää versoissa, mutta ei juurissa (Owens \& Stover 1999). Hiilihydraattien ja typen kasvaneet määrät käsittelyvuonna eivät kuitenkaan vaikuttaneet omenalla seuraavan kesän kasvuun. 
Taulukko 2. Proheksadioni-kalsiumin vaikutus eri aikoihin merkittyjen lehtien ruotien keskimääräiseen pituuteen käsittelyvuonna ja käsittelyä seuraavan vuoden keväänä. Keskiarvo (mm) \pm keskihajonta (mm), vaihtoehtohypoteesi on kaksisuuntainen $\mathrm{H}_{1} \neq$ kontrolli.

\begin{tabular}{|c|c|c|c|c|c|c|c|c|c|c|c|}
\hline \multirow{3}{*}{$\begin{array}{l}\text { ProCa- } \\
\text { käsittely } \\
0 \mathrm{nnm}\end{array}$} & \multicolumn{6}{|c|}{2004} & \multicolumn{5}{|c|}{2005} \\
\hline & käsittelyn aikaan & \multicolumn{2}{|c|}{2 vkoa käsittelystä } & \multicolumn{3}{|c|}{4 vkoa käsittelystä } & \multicolumn{3}{|c|}{ toukokuussa } & \multicolumn{2}{|c|}{ kesäkuussa } \\
\hline & $86,7 \pm 7,6$ & $98,3 \pm$ & 10,3 & $120,2 \pm$ & 17,0 & & $114,1 \pm$ & 8,9 & & $191,6 \pm$ & 14,6 \\
\hline $100 \mathrm{ppm}$ & $68,4 \pm 4,1 * *$ & $92,6 \pm$ & 1,8 & $136,9 \pm$ & 6,5 & o & $130,1 \pm$ & 6,1 & $*$ & $224,3 \pm$ & 21,0 \\
\hline $200 \mathrm{ppm}$ & $66,1 \pm 3,0 \quad * *$ & $90,0 \pm$ & 3,2 & $135,1 \pm$ & 6,2 & & $145,8 \pm$ & 9,9 & $* *$ & $228,4 \pm$ & 6,4 \\
\hline
\end{tabular}

\section{Vuoden 2005 mittaukset}

ProCa lisäsi toukokuussa ja kesäkuussa 2005 esiinkasvaneiden lehtien ruotien pituutta (Taulukko 2). ProCan vaikutus lehtiruotien pituuteen keväällä 2005 tuskin aiheutuu yhdisteen suorasta vaikutuksesta lyhyestä puoliintumisajasta johtuen. Pituuden kasvu johtuu todennäköisesti suuremman sivujuurakkomäärän aiheuttamasta valon vähenemisestä lehdistön sisällä, mikä johtaa normaaliin varjon aiheuttamaan pituuskasvun edistymiseen.

Käsittelyjen väliset erot kukintojen lukumäärissä olivat samansuuntaisia kuin erot juurakoidenkin määrissä. Vahvempi ProCa-käsittely lisäsi kukintojen määrää neljällä kukinnolla ja laimeampi käsittely kahdella kukinnolla tainta kohti kontrolliin verrattuna, mutta vain vahvemman käsittelyn vaikutus oli merkitsevä ( $\mathrm{p}$-arvo $=0,0183$, vaihtoehtohypoteesi yksisuuntainen $\mathrm{H}_{1}>$ kontrolli). Aiemmin tehdyssä tutkimuksessa ProCan ei havaittu lisäävän käsittelyä seuraavan kevään kukintojen määrää mansikalla (Black 2004).

Satoaika alkoi kontrollikäsitellyissä taimissa 5.7, 100 ppm -käsitellyissä taimissa keskimäärin kaksi päivää ja 200 ppm -käsitellyissä taimissa keskimäärin kolme päivää myöhemmin. Black (2004) ei havainnut eroja kukinnan alkamisessa Chandler-lajikkeella. Käytännössä kolmen päivän ero sadon alkamisessa ei vielä ole merkittävän suuri.

Vahvempi ProCa-käsittely kasvatti taimikohtaisen sadon puolitoistakertaiseksi (Taulukko 3). Käytännössä ProCa lisäsi taimesta keruukerralla saatavaa keskimääräistä satoa ja taimesta saatujen marjojen määrää vaikuttamatta kuitenkaan keskimääräiseen marjan painoon. Toisaalta Black (2004) ei havainnut ProCan vaikuttavan Chandler-lajikkeen satoon Yhdysvalloissa. Erilaiset kasvuolosuhteet saattavat selittää poikkeavat tulokset. Omenalla ja päärynällä ProCan on havaittu kasvattavan käsittelyvuoden satoa lievästi, mutta hedelmien koko voi samalla pienentyä (Rademacher ym. 2004). Päärynällä käsittelyt tehdään aikaisin keväällä versonkasvun hillitsemiseksi, joten seuraavan vuoden kukka-aiheiden muodostuessa ProCa on hävinnyt kasvista eikä siten edistä seuraavan vuoden kukintaa. ProCan hajottua aktiivisen gibberelliinin määrä lisääntyy, jolloin ProCalla saattaa olla epäsuora estävä vaikutus kukintaan (Sugar ym. 2004). Loppukesän ProCa-käsittely voi lisätä kukkaaiheiden määrää joillain omenalajikkeilla, mutta ei lisää seuraavan vuoden satoa (Owens \& Stover 1999).

Taulukko 3. Proheksadioni-kalsiumin vaikutus mansikan taimien keskimääräiseen sadonmuodostukseen käsittelyvuotta seuraavana kesänä. Keskiarvo \pm keskihajonta, vaihtoehtohypoteesi on yksisuuntainen $\mathrm{H}_{1}>$ kontrolli.

\begin{tabular}{|c|c|c|c|c|c|c|c|c|c|c|}
\hline \multirow{2}{*}{$\frac{\text { ProCakäsittely }}{0 \mathrm{ppm}}$} & \multicolumn{4}{|c|}{ sato $(\mathrm{g})$} & \multicolumn{2}{|c|}{ sato $(\mathrm{g})$ /keräyskerta } & \multicolumn{4}{|c|}{ sato $(\mathrm{kpl})$} \\
\hline & 471,0 & \pm & 74,8 & & $44,2 \pm$ & 6,4 & 53 & & 7 & \\
\hline $100 \mathrm{ppm}$ & 600,0 & \pm & 132,8 & & $62,6 \pm$ & $15,0 \quad$ o & 70 & \pm & 13 & $\mathrm{o}$ \\
\hline $200 \mathrm{ppm}$ & 719,2 & \pm & 195,9 & $* *$ & $79,8 \pm$ & $24,4 * *$ & 87 & \pm & 21 & $* *$ \\
\hline
\end{tabular}

Kontrollikäsittelyssä taimet antoivat tasaisen satokertymän (Kuvio 1). Vahvemmassa ProCakäsittelyssä sato kertyi hitaan alun jälkeen nopeasti. Kolmannella satoviikolla vahvimman ProCakäsittelyn saaneista taimista kertyi merkitsevästi enemmän satoa kuin kontrolli- ja heikomman ProCakäsittelyn saaneista taimista. Parhaimmillaan kolmannen satoviikon aikana saatu sadonlisäys oli keskimäärin 200 g/taimi. Marjojen koko pieneni varsin nopeasti kaikissa käsittelyissä: ensimmäisen 
keruukerran marjakoko oli keskimäärin 20,1 g, toisen keruukerran 13,6 g ja kolmannen noin 11,6 g. ProCa ei kuitenkaan vaikuttanut marjojen keskimääräiseen kokoon, joka oli 9,4-9,8 g, eikä koon muutokseen. Myöskään Black (2004) ei havainnut ProCan vaikuttavan marjan kokoon.

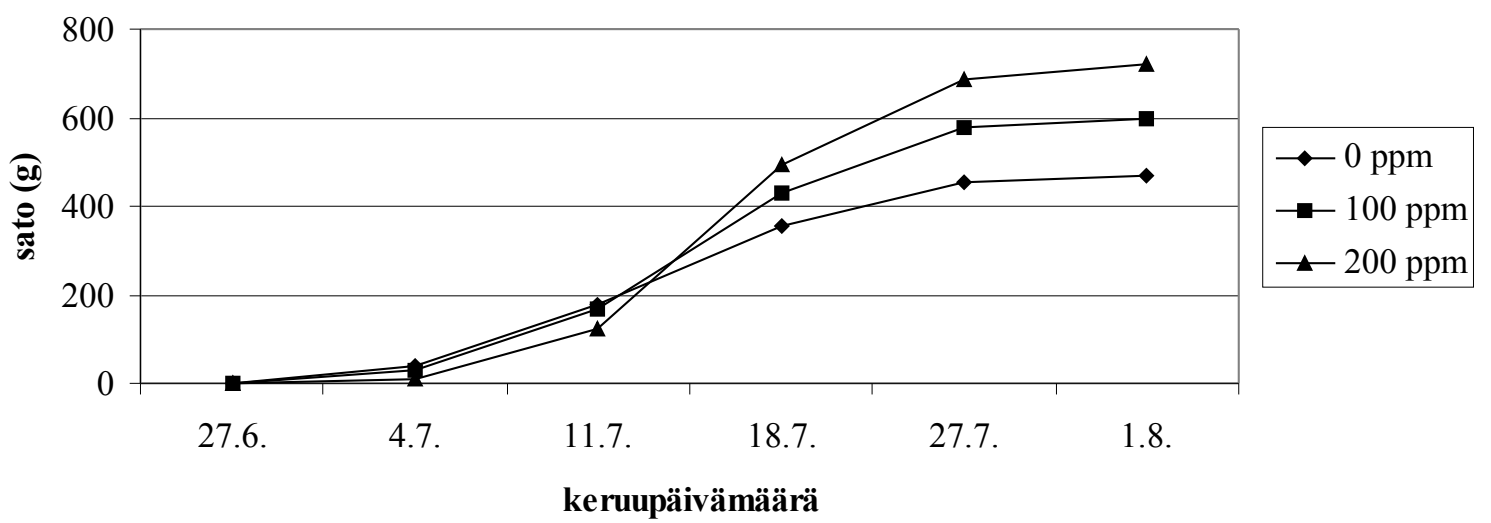

Kuvio 1. Proheksadioni-kalsiumin vaikutus mansikantaimen keskimääräiseen satokertymään käsittelyä seuraavana kesänä.

Vahvin ProCa-käsittely lisäsi kauppakelvottomien marjojen kokonaismäärää, mutta ei kuitenkaan vaikuttanut kauppakelvottoman sadon suhteelliseen osuuteen koko sadon määrästä. Kauppakelvottomien marjojen prosenttiosuudet olivat keskimäärin 11-14 \% välillä.

\section{Johtopäätökset}

Istutusvuonna annetulla ProCa-käsittelyllä voidaan kasvattaa seuraavan vuoden satopotentiaalia mansikalla. Kuukausi istutuksen jälkeen annettu ProCa-käsittely hillitsee taimien rönsyntuotantoa ja lisää juurakon haaroittumista, mikä näkyy merkittävänä sadonlisäyksenä seuraavana vuonna. Käytännössä marjojen lukumäärä kasvaa marjakoon kuitenkaan pienenemättä. Tekemiemme kokeiden perusteella rönsynmuodostuksen merkittävään vähentämiseen vaaditaan vähintään 200 ppm vahvuinen käsittely, mutta sivujuurakoiden määrä lisääntyi merkittävästi jo 100 ppm:n ProCa-pitoisuudella. Vahvemmalla pitoisuudella ProCa kuitenkin lisäsi haaroittumista enemmän, jolloin taimikohtainen sato puolitoistakertaistui kontrolliin verrattuna. Aikaisemmalla käsittelyllä ja sen myöhemmällä toistamisella voisi olla mahdollista päästä matalammalla ProCa-pitoisuudella tehokkaampaan rönsynmuodostuksen hallintaan, jolloin yhteyttämistuotteita voitaisiin vielä paremmin suunnata seuraavan vuoden satopotentiaalin muodostukseen. Jatkotutkimuksissa selvitämme voidaanko seuraavan kesän satoa lisätä sadonkorjuun jälkeisellä ProCa-käsittelyllä vanhemmilla kasvustoilla.

\section{Kirjallisuus}

Black, B. L. 2004. Prohexadione-calcium decreases fall runners and advances branch crowns of 'Chandler' strawberry in a cold-climate annual production system. J. Amer. Soc. Hort. Sci. 129: 479-485.

Dana, M. N. 1981. The strawberry plant and its environment. Teoksessa: Childers, N. F. (toim.) The strawberry. Cultivars to marketing. 1. painos. Horticultural Publications. Jainsville, Florida, USA. s. 32-44.

Evans, J. R., Evans, R. R., Regusci, C. L. \& Rademacher, W. 1999. Mode of action, metabolism, and uptake of BAS 125W, prohexadione-calcium. HortScience 34: 1200-1201.

Glenn, D. M. \& Miller, S. S. 2005. Effects of Apogee on growth and whole-canopy photosynthesis in Spur 'Delicious' apple trees. HortScience 40: 397-400.

Griggs, D. L., Hedden, P., Temple-Smith, K. E. \& Rademacher, W. 1991. Inhibition of gibberellin $2 \beta$ -hydroxylases by acylcyclohexanedione derivatives. Phytochemistry 30: 2513-2517.

Grossmann, K., König-Krantz, S. \& Kwiatkowski, J. 1994. Phytohormonal changes in intact shoots of wheat and oilseed rape treated with the acylcyclohexanedione growth retardant prohexadione-Calcium. Physiol. Plant. 90: 139-143.

Guttridge, C. G. 1985. Fragaria $x$ ananassa. Teoksessa: Halevy, A. H. (toim.) CRC handbook of flowering volume III. CRC Press. Boca Baton, Florida, USA. s. 16-33. 
Hytönen, T., Palonen, P., Mouhu, K. \& Junttila, O. 2004. Crown branching and cropping potential in strawberry (Fragaria x ananassa Duch.) can be enhanced by daylength treatments. J. Hortic. Sci. Biotech. 79: 466-471.

Ilias, I. F. \& Rajapakse, N. 2005. Prohexadione-calcium affects growth and flowering of petunia and impatiens grown under photoselective films. Sci. Hortic. 106: 190-202.

Medjdoub, R., Val, J. \& Blanco, A. 2005. Inhibition of vegetative growth in red apple cultivars using prohexadione-calcium. J. Hortic. Sci. Biotech. 80: 263-271.

Nishizawa, T. 1993. The effect of paclobutrazol on growth and yield during first year greenhouse strawberry production. Sci. Hortic. 54: 267-274.

Norelli, J. L. \& Miller, S. S. 2004. Effect of prohexadione-calcium dose level on shoot growth and fire blight in young apple trees. Plant Dis. 88: 1099-1106.

Owens, C. L. \& Stover, E. 1999. Vegetative growth and flowering of young apple trees in response to prohexadione-calcium. HortScience 34: 1194-1196.

Rademacher, W. 2000. Growth retardants: effects on gibberellin biosynthesis and other metabolic pathways. Annu. Rev. Plant Physiol. Plant Mol. Biol. 51: 501-531.

Rademacher, W. \& Kober, R. 2003. Efficient use of prohexadione-ca in pome fruits. Europ. J. Hort. Sci. 68:101-107.

Rademacher, W., van Saarloos, K., Garuz Porte, J. A., Riera Forcades, F., Senechal, Y., Andreotti, C., Spinelli, F., Sabatini, E. \& Costa, G. 2004. Impact of prohexadione-Ca on the vegetative and reproductive performance of apple and pear trees. Europ. J. Hort. Sci 69: 221-228.

Reekie, J. Y. C. \& Hicklenton, P. R. 2002. Strawberry growth response to prohexadione-calcium. Strawberry research to 2001. Proceedings of the 5th North American Strawberry Conference 147-152.

Robertson, M. \& Wood, C. A. 1954. Studies in the development of strawberry. I. Flower-bud initiation and development in early- and late-formed runners in 1951 and 1952. J. Hortic. Sci. 29: 104-111.

Sugar, D., Elfving, D. C. \& Mielke, E. A. 2004. Effects of prohexadione-calcium on fruit size and return bloom in pear. HortScience 39: 1305-1308.

Thompson, P. A. \& Guttridge, C. G. 1959. Effect of gibberellic acid on the initiation of flowers and runners in the strawberry. Nature 184: BA72-BA73. 